\title{
GERAKAN TANPA SEDOTAN: HINDARI KERUSAKAN LINGKUNGAN
}

\author{
Dara Fatia $^{1}$, Yogi Suprayogi Sugandi ${ }^{2}$ \\ ${ }^{1}$ Program Pascasarjana Sosiologi, FISIP, Universitas Padjadjaran \\ dara.fatia@yahoo.com
}

\begin{abstract}
ABSTRAK
Kerusakan lingkungan yang diakibatkan gaya konsumtif masyarakat modern membuat kerugian tidak hanya pada kehidupan masyarakat itu sendiri melainkan juga seluruh makhluk hidup. Gerakan sosial dilakukan masyarakat untuk meningkatkan kesadaran dan keberdayaan masyarakat dalam pelestarian fungsi lingkungan hidup. Studi ini mengkaji tentang isu gerakan sosial baru yaitu \#NoStrawMovement. Gerakan \#NoStrawMovement mengajak masyarakat untuk berpartisipasi dalam menjaga dan merawat lingkungan mereka sendiri dengan mengurangi pengurangan sedotan plastik. Tujuan dari penelitian ini ialah mengetahui sejauh mana kefektifan gerakan \#NoStrawMovement dalam mempengaruhi prilaku masyarakat untuk mengantipasi kerusakan Lingkungan. Penelitian ini menggunakan metode kualitatif dengan studi deskriptif yang bertujuan untuk menggambarkan keseluruhan permasalahan penelitian. Hasil penelitian menunjukan bahwa keberhasilan gerakan ini dibuktikan dengan berkurangnya pengguaan sedotan plastik secara signifikan dikalangan masyarakat. keberhasilan ini juga dipengaruhi oleh beberapa restaurant makanan yang tidak lagi menyediakan sedotan plastik bagi masyarakat. Seperti virus yang terus menyebar, gerakan anti sedotan plastik ini terus meluas dan membuat kesadaran bagi hampir setiap kalangan masyarakat.
\end{abstract}

Kata kunci: Gerakan sosial baru, \#NoStrawMovement, sedotan plastik dan kerusakan lingkungan.

\begin{abstract}
Environmental damage caused by the consumptive style of modern society causes harm not only to the life of the community itself but also to all living things. The social movement is carried out by the community to increase community awareness and empowerment in preserving environmental functions. This study examines the issue of new social movements, namely \#NoStrawMovement. The \#NoStrawMovement movement invites people to participate in maintaining and caring for their own environment by reducing the reduction of plastic straws. The purpose of this study is to determine the extent of the effectiveness of the \#NoStrawMovement movement in influencing community behavior to anticipate environmental damage. This study uses qualitative methods with descriptive studies that aim to describe the overall problem of the research. The results showed that the success of this movement was evidenced by the significant reduction in the use of plastic straws among the public. This success was also influenced by several food restaurants that no longer provided plastic straws for the community. Like a virus that continues to spread, the anti-plastic straw movement continues to expand and create awareness for almost every community.
\end{abstract}

Keywords: New social movements, \#NoStrawMovement, plastic straws and environmental damage.

2 Prodi Pascasarjana Sosiologi, Fakultas Ilmu Sosial dan Ilmu Politik, Universitas Padjadjaran yogi.suprayogi@unpad.ac.id 


\section{PENDAHULUAN}

Kerusakan lingkungan hidup yang disebabkan oleh banyaknya sampah-sampah plastik nyatanya tidak hanya merugikan manusia, namun juga seluruh makhluk hidup. Menurut Divers Clean Action, LSM yang beranggotakan komunitas muda yang memusatkan perhatian pada isu-isu sampah laut di Indonesia, sedikitnya 93 juta sedotan plastik perhari yang dihasilkan masyarakat (Intan, 2018). Indonesia menduduki peringkat ke 4 dalam menghasilkan sampah sedotan plastik. Hal ini menjadi sangat serius karena sampah yang dihasilkan melalui sedotan plastik susah untuk di daur ulang sehingga sangat mencemari lingkungan dan merusak ekosistem terutama laut.

Permasalahan sampah yang sangat mendunia dan menyebabkan kerusakan lingkungan yang begitu cepat, maka diperlukan upaya konkret dan berkelanjutan dalam perlindungan dan pelestarian fungsi lingkungan hidup. Menurut (Ahmad, 2010), gerakan kultural dalam menjaga lingkungan perlu digalakkan dengan menciptakan lingkungan yang sehat dan bersih melalui keyakinan, pemahaman dan prilaku ekologis manusia dalam kehidupan sosialnya. Gerakan sosial dilakukan masyarakat untuk meningkatkan kesadaran dan keberdayaan masyarakat dalam pelestarian fungsi lingkungan hidup. Gerakan sosial merupakan agen perubah yang dapat membantu pemerintah dalam upaya perlindungan dan pengelolaan lingkungan hidup sehingga fungsi lingkungan akan tetap lestari (Farma Rahayu, F. Susanto, \& Sukma Muliya, 2018).

Modernisasi sebagai gerakan sosial sesungguhnya bersifat revolusioner (perubahan cepat dari tradisi ke moderen). Modernisasi menimbulkan perubahan di berbagai bidang nilai, sikap dan kepribadian. Sebagian besar permasalahan ini terkaji dalam sikap individu yang lebih modern. Perubahan yang dimaksud adalah perubahan yang biasanya terjadi bersamaan dengan usaha modernisasi. Perubahan yang direncanakan, paling baik dilakukan pada masyarakat yang memang sebelumnya sudah mempunyai keinginan untuk mengadakan perubahan, tetapi tidak mampu melakukannya. Dalam kondisi demikian, masyarakat akan serta merta menerima perubahan yang dilakukan oleh agent of change. Pihak-pihak yang ingin mengadakan perubahan dinamakan agent of change, yaitu seseorang atau sekelompok orang yang mendapat kepercayaan masyarakat sebagai pemimpin satu atau lebih lembaga-lembaga kemasyarakatan. Dalam melaksanakannya, agent of change langsung tersangkut tekanan-tekanan untuk mengadakan perubahan. Bahkan mungkin menyiapkan pula perubahan-perubahan pada lembaga kemasyarakatan lainnya. Suatu perubahan yang direncanakan atau dikehendaki tersebut selalu berada dibawah pengendalian serta pengawasan agent of change tersebut (Ushuluddin, n.d.). Mengikuti Founder Divers Clean Action Swietenia Puspa Lestari melandasi peluncuran gerakan 
\#\#NoStrawMovement mereka pada tahun 2017 lalu sebagai respon menyikapi banyaknya sampah sedotan plastik yang mengotori perairan dan pantai di Indonesia (Anto, 2018).

Tujuan dari penelitian ini adalah untuk mengetahui bagaimana kefektifan gerakan \#NoStrawMovement dalam mempengaruhi prilaku masyarakat untuk mengantipasi kerusakan Lingkungan. Gerakan ini mengajak warga peduli dengan dampak sedotan plastik sekali pakai terhadap lingkungan. Remahan plastik atau mikroplastik dari sedotan yang masuk ke lautan akan dimakan binatang laut yang akhirnya akan dikonsumsi manusia. Selain mengajak warga, gerakan ini juga melibatkan para pelaku industri untuk peduli dengan dampak lingkungan dari sedotan plastik dengan tidak lagi menyediakan sedotan plastik.

\section{METODE PENELITIAN}

Lokasi pada penelitian terletak di Tubagus Ismail, Kecamatan Coblong, Bandung, Indonesia. Teknik pengumpulan data dilakukan dengan metode kepustakaan dan metode lapangan. Pengolahan data menggunakan anlisis kualitataif deskriptif, data yang telah dikumpulkan direduksi, dilanjutkan dengan penyajian data lalu diverifikasi dan dilakukan penarikan kesimpulan. Subjek dalam penelitian ini berjumlah 7 (tujuh) orang, dimana 5 (lima) orang menjadi informan kunci dan 2 (dua) sebagai informan pendukung penguatan data. Untuk menentukan informan dalam penelitian dilakukan dengan menggunakan purposive sampling. Peneliti memilih sendiri informan yang akan diteliti menurut ciri-ciri spesifik yang dimiliki sampel itu. Teknik ini didasarkan pada tujuan tertentu dengan tetap mempertahankan karakteristik subjek penelitian.

\section{KERANGKA TEORI/KONSEP}

Perkembangan gerakan sosial baru (Sukmana, 2013) dipandang sebagai produk dari kekuatankekuatan lingkungan (environmental forces) baik bersifat internal maupun eksternal terhadap gerakan. Faktor-faktor internal meliputi: kepemimpinan (leadership), tingkat ketersediaan sumberdaya (level of available resources), ukuran kelompok (group size), dan tingkat dari organisasi internal (degree of internal organization). Sedangkan faktok-faktor eksternal meliputi: tingkat represi dari masyarakat (the level of societal repression), tingkat simpatisan eksternal (extent of external sympathizers), serta jumlah dan kekuatan kelompok politik (number and strength of polity groups).

Teori strukturasi oleh Anthony Giddens dianggap mampu untuk menganlisis isu gerakan sosial baru. Tujuan fundamental teori strukturasi adalah menjelaskan hubungan saling memengaruhi antara agen dan struktur. Kondisi tidak terpisahkan antara agen dan struktur ini lah yang dimaksud Giddens dengan dualitas. Seluruh tindakan sosial memerlukan struktur dan seluruh 
struktur membutuhkan tindakan sosial (Ritzer, 2011). Sementara itu dalam konteks dualisme, agen dan struktur merupakan dua hal yang terpisah dan cenderung bertentangan. Pada konsep dualitas, tindakan-tindakan agen yang berulang-ulang akan menciptakan suatu pola atau jejak memori yang memungkinkan tersedianya kondisi dimana tindakan serupa dapat dilakukan oleh agen-agen lain. Struktur dalam konsepsi Giddens itu hadir hanya dalam perwujudan melalui praktik-praktik tertentu dan sebagai jejak memori yang berorientasi pada perilaku manusia sebagai agen yang berpengetahuan (Madubrangti, 2015). Struktur sebagai jejak memori dan perwujudan praktik-praktik yang berulang menjadi sesuatu yang membatasi tapi sekaligus juga memungkinkan tindakan-tindakan dikemudian hari. Struktur disini berperan sebagai medium sekaligus hasil dari praktik sosial yang berulang dan terorganisir. Melalui aktivitas-aktivitas berupa gebrakan peduli lingkungan, agen-agen (pemimpin) mereproduksi kondisi-kondisi yang memungkinkan dilakukannya aktivitas tadi. Seperti kampanye \#NoStrawMovement. Beberapa aktor yang sudah duluan menyerukan isu ini terus membagi dan memposting seruan untuk tidak menggunakan sedotan plastik di media sosial.

Melalui tindakan itu sesungguhnya individu tadi telah mereproduksi nilai-nilai dan kondisi yang akan memungkinkan orang lain di waktu lain melakukan hal serupa, setidaknya dengan meningkatkan rasa kewajaran untuk melakukan hal yang sama. Nilai kewajaran yang digunakan orang-orang secara berulang ketika menggunakan media sosial sebagai alat untuk mengkampanyekan isu peduli lingkungan kemudian menjadi suatu sistem budaya berkomunikasi atau dengan kata lain menjadi bagian dari praktik-praktik rekursif yang membentuk struktur budaya komunikasi.

\section{Perubahan Sosial}

Rogers mengemukakan bahwa perubahan sosial adalah suatu proses yang melahirkan perubahan-perubahan di dalam struktur dan fungsi dari suatu sistem kemasyarkatan, Sedangkan Selo Soemarjan dan Soelaeman Soemardi mengemukakan bahwa perubahan sosial diartikan sebagai suatu variasi dari cara-cara hidup yang telah diterima, baik karena perubahan-peubahan kondisi geografis, kebudayaan material, komposisi penduduk, idiologi, maupun karena adanya difusi atau penemuan-penemuan baru dalam masyarakat tersebut (Ushuluddin, n.d.).

Modernisasi dan perubahan sosial pada dasarnya merupakan sebuah gagasan tentang perubahan sosial dalam perjalanannya telah menjadi sebuah idiologi. Perkembangan ini adalah akibat dari dukungan dana dan politik luar biasa besarnya dari pemerintah dan organisasi maupun perusahaan swasta di Amerika Serikat serta negara-negara liberal lainnya. Semua itu 
menjadikan modernisasi dan pembangunan sebagai suatu gerakan ilmuwan antardisiplin ilmu-ilmu sosial yang memfokuskan kajian terhadap perubahan sosial. Akibatnya menjadikan teori modernisasi tidak hanya sekedar merupakan "industri yang sedang tumbuh", tetapi telah menjadi sebuah aliran pemikiran (a school of thought), bahkan telah menjadi sebuah idiologi. Pengaruh modernisasi di dunia ketiga sangat luas, tidak hanya pada kalangan akademisi di Perguruan Tinggi, tetapi juga kalangan birokrasi yakni para perencana dan pelaksana program pembangunan di negara-negara dunia ketiga.

Modernisasi hampir pada awalnya akan mengakibatkan disorganisasi dalam masyarakat. Apalagi modernisasi mulai menyangkut nilai-nilai masyarakat dan norma-norma masyarakat. Proses yang begitu cepat serta tidak mengenal istirahat hanya dapat menyebabkan disorganisasi yang terus menerus, karena masyarakat tidak pernah sempat untuk mengadakan reorganisasi. Salah satu faktor psikologi-sosial yang penting bagi modernisasi adalah komitmen rakyat atau sekurang-kurangnya keinginan mereka untuk menjadi moderen, karena itulah sebagian besar waktu dan tenaga pemimpin politik dicurahkan untuk menjamin dan memantapkan komitmen atau keinginan rakyat (Ushuluddin, n.d.).

\section{Gerakan Sosial Baru}

Perubahan sosial yang diakibatkan dari modernisasi menyebabkan konsep gerakan sosial menjadi lebih luas. Konsep gerakan sosial secara teoritis merupakan sebuah gerakan yang terbangun berdasarkan prakarsa masyarakat dengan tujuan untuk melontarkan tuntutan atas perubahan dalam institusi maupun kebijakan dari pemerintah yang dirasa sudah maupun tidak sesuai lagi dengan kehendak sebagian mayarakat (Yuanjaya, 2018).

Isu tentang gerakan sosial baru atau new social movement akhir-akhir ini gencar mewarnai wacana dan perdebatan dalam kehidupan sosial masyarakat. Sebenarnya isu gerakan sosial bukanlah hal baru melainkan sudah ada ketika era kolonialisme belanda, gerakan sosial ini muncul dikarenakan pemberotakan para petani pada zaman tersebut (Suharko, 2006). Mulanya, Gerakan sosial lebih menitik fokuskan pada permasalahan ekonomi, dan ideologi politik tertentu, kini gerakan sosial yang sudah lebih berevolusi menjadikannya suatu konsep gerakan sosial baru dengan kajian lebih luas. Gerakan sosial baru memfokuskan pada kaitan isu-isu simbolik dan kebudayaan, menerima pluralisme ide serta cenderung mengembangkan pandangan pragmatis dalam upaya menciptakan sistem partisipasi politik seluas-luasnya dalam proses pengambilan keputusan (Sari \& Siahainenia, 2017). Gerakan sosial baru bersifat terbuka tanpa menghiraukan latar belakang kelas sosial, etnisitas, politik, maupun agama dalam kehidupan sosial masyarakat. Atas dasar ini, gerakan sosial baru dikategorikan sebagai suatu perkumpulan yang inklusif dan diprakarsai aktor-aktor dan diikuti kelompok- kelompok 
yang secara sadar memobilisasi diri untuk bersama-sama memperjuangkan democratization of everyday life (Sari \& Siahainenia, 2017).

Tujuan lain dari gerakan sosial baru (New Social Movement) adalah untuk menata kembali relasi negara, masyarakat dan perekonomian untuk menciptakan ruang publik yang di dalamnya terdapat wacana demokratis otonomi dan kebebasan individual. Gerakan Sosial baru (New Social Movement) mempunyai karakter yang lain yaitu, Framing (pembingkaian), framing (pembingkaian) adalah suatu bentuk cara pandang individu terhadap fenomena yang dipengaruhi oleh ideologi di dalam dirinya (Yuanjaya, 2018). Dengan kata lain, frame menentukan sikap individu terhadap suatu fenomena. Framing dalam gerakan sosial lebih dapat dianggap sebagai cara atau strategi yang digunakan untuk menyamakan pandangan baik dari pelaku maupun dari masyarakat terhadap suatu isu tertentu.

Gerakan sosial juga tidak selalu berhasil dalam melaksanakan suatu perubahan. Menurut (Sari \& Siahainenia, 2017) faktor yang menjadi penyebab kegagalan dalam menjalankan gerakan sosial, diantaranya adalah semakin berkurangnya kemampuan aktor- aktor pendukung perjuangan walaupun sudah menggunakan simbol-simbol budaya karena negara telah melakukan kontrol atau campur tangan dengan mempersempit ruang publik yang dapat membangun jejaring dan untuk membukanya perlu dikemukakan wacana otonomi dan kebebasan individu, kolektivitas, dan identitas.

\section{PEMBAHAHASAN}

\section{Gerakan Mengurangi Sampah Sedotan Plastik}

Masyarakat atau komunitas diartikan sebagai sekelompok orang yang berkumpul dengan nasib yang sama dan alasan yang sama. Komunitas tersebut menjadi bagian dari konsep diri seseorang dan merupakan aspek penting sebagai sudut pandang atau prilaku individu. Sejauh masyarakat melakukan rutinitas dengan semakin meningkatkan pemanasan global, tak sedikit pula beberapa masyarakat lain sadar akan mengurangi perilakunya yang merusak lingkungan dan ekosistem. Gerakan lingkungan oleh masyarakat muncul sebagai tanggapan atas kegagalan kebijakan lingkungan pemerintah kota dalam mengatasi dampak negatif dari degradasi lingkungan (Yuanjaya, 2018).

Kerusakan lingkungan yang semakin tidak terkondisikan menyebabkan para aktivis muda gencar untuk mengkampanyekan aktivitas pengurangan sampah plastik. Hal ini dikarenakan beberapa sampah plastik dapat mengganggu hormon penting untuk kesehatan, dan plastik sendiri bertindak seperti magnet untuk berbagai racun dan polutan lain yang manusia tumpahkan ke alam. Faktanya pertahun 2017 diperkirakan keadaan laut sekarang telah 
mengandung sekitar 51 triliun partikel mikroplastik, yang mana 500 kali lebih banyak daripada bintang-bintang di galaksi kita ini. Mirisnya, limbah plastik ini pun ditemukan sebanyak 300 miliar kepingan di Arktik yang sebelumnya merupakan pulau murni dan terpencil di Pasifik, dan ditemukan pula di Pulau Henderson yang adalah pulau tidak berpenghuni dan diyakini memiliki konsentrasi tertinggi polusi plastik di dunia (Ananda, 2018).

Dampak sampah plastik terhadap lingkungan antara lain adalah tercemarnya tanah, air, dan makhluk bawah tanah. Sampah plastik yang berada dalam tanah yang tidak dapat diuraikan oleh mikroorganisme menyebabkan mineral-mineral dalam tanah baik organik maupun anorganik semakin berkurang, hal ini menyebabkan berkurangnya fauna tanah, seperti cacing dan mikorganisme tanah, yang hidup pada tanah tersebut dikarenakan sulitnya untuk memperoleh makanan dan berlindung. Selain itu kadar O2 dalam tanah semakin sedikit, sehingga fauna tanah sulit untuk bernafas dan akhirnya mati dan berdampak langsung pada tumbuhan yang hidup pada area tersebut.

Salah satu gerakan sosial yang aktif mengencarkan pengurangan penggunaan sampah plastik adalah gerakan sosial stop penggunaan sedotan plastik atau yang lebih di kenal sebagai gerakan \#NoStrawMovement. Gerakan ini mengajak masyarakat untuk peduli dengan dampak sedotan plastik sekali pakai terhadap lingkungan. \#NoStrawMovement juga mengajak para pelaku industri untuk peduli dengan dampak lingkungan dari sedotan plastik dengan tidak lagi menyediakan sedotan plastik. Sebagai permulaan, gerakan ini berhasil menggandeng satu perusahaan waralaba makanan cepat saji terbesar di Indonesia untuk berkomitmen tidak menyediakan lagi sedotan plastik di jaringan gerai mereka dan saat ini sudah ada 4 perusahaan multinasional lain yang ikut bergabung disamping pemilik usaha kecil dan menengah lokal yang mereka edukasi di sejumlah tempat (Anto, 2018).

Untuk mulai menggugah kepedulian dan mendidik masyarakat tentang bahaya sampah sedotan plastik bagi lingkungan, restoran cepat saji, yaitu McDonald's Indonesia meluncurkan gerakan \#NoStrawMovement pada 12 November 2018 lalu. Associate Director Communication McDonald's Indonesia Sutji Lantyka dalam (Intan, 2018) mengatakan 190 gerai McDonald's di seluruh Indonesia sudah tidak menyediakan dispenser sedotan plastik. Namun, masih ada beberapa minuman di McDonald's Indonesia yang masih pakai sedotan, dan kalau ada konsumen yang ingin memakai sedotan bisa meminta kepada petugas di restoran tersebut. Sama halnya dengan travel blogger yang juga social media influencer Febrian (Intan, 2018). Berawal dari hobi jalan-jalan ke laut dan selalu menemukan sampah sedotan plastik baik di laut maupun di pantai, Febrian kini tidak lagi menggunakan sedotan plastik. Terlebih ketika ia mengetahui dari sebuah artikel yang dibacanya bahwa Indonesia merupakan salah satu negara 
penghasil sampah sedotan plastik terbanyak di dunia. Febrian akhirnya memutuskan untuk tidak menggunakan lagi sedotan plastik dan mencoba mendidik masyarakat di sosial media untuk mengurangi, bahkan kalau bisa untuk tidak lagi menggunakan sedotan plastik tersebut. Febrian pun bekerja sama dengan salah satu produsen sedotan stainless dimana sebagian penjualannya akan disumbangkan ke bidang konservasi yang membutuhkan. Secara nasional, Hendra dalam (Juniman, 2018) menargetkan gerakan ini mampu menurunkan penggunaan sedotan plastik hingga 100 persen. Namun, dia menyadari hasil ini tak bakal didapat dalam jangka yang cepat. Selain itu, Hendra juga menyebut perusahannya tengah mencari cara untuk mengganti sedotan berukuran besar untuk minuman berjenis float dan sedotan tipis untuk minuman hangat seperti kopi yang masih disediakan di gerai-gerai di tokonya. Hendra mengatakan jenis sedotan itu rencananya bakal diganti dengan bahan lain yang ramah lingkungan.

Gerakan tanpa sedotan plastik atau \#Nostrawmovement yang sukses dijalankan di Indonesia, kemudian diadopsi oleh negara tetangga, Singapura (Juniman, 2018). Gerakan ini kini juga sedang dikaji untuk ditiru oleh Filipina dan Australia. Gerakan tanpa sedotan plastik yang diterapkan Singapura ini merupakan kampanye yang diinisiasi oleh KFC Indonesia sejak pertengahan tahun lalu. Gerakan ini membuat gerai KFC tak lagi menyediakan langsung sedotan plastik berukuran kecil dengan menghilangkan dispenser sedotan. Sedotan plastik hanya diberikan jika konsumen benar-benar membutuhkannya dan meminta langsung ke pelayan. Gerai cepat saji serupa di Singapura ini mulai menerapkan gerakan serupa per 20 Juni lalu pada 84 outlet di Singapura. Berdasarkan keterangan pers yang dikutip dari Channel News Asia (Juniman, 2018), gerakan ini menargetkan untuk mengurangi 7,8 metrik ton sedotan plastik sekali pakai dalam setahun. Secara nasional, Hendra menargetkan gerakan ini mampu menurunkan penggunaan sedotan plastik hingga 100 persen, namun memerlukan waktu untuk membuat perubahan tersebut.

\section{SIMPULAN}

Modernisasi sebagai gerakan sosial sesungguhnya bersifat revolusioner (perubahan cepat dari tradisi ke moderen). Modernisasi menimbulkan perubahan di berbagai bidang nilai, sikap dan kepribadian. Sebagian besar permaslaaha ini terhimpun dalam konsep "manusia moderen". Perubahan yang dimaksud adalah perubahan yang biasanya terjadi bersamaan dengan usaha modernisasi. Perubahan yang direncanakan, paling baik dilakukan pada masyarakat yang memang sebelumnya sudah mempunyai keinginan untuk mengadakan perubahan, tetapi tidak mampu melakukannya. Dalam kondisi demikian, masyarakat akan serta merta menerima perubahan yang dilakukan oleh agent of change. 
Perubahan sosial yang diakibatkan dari modernisasi menyebabkan konsep gerakan sosial menjadi lebih luas. Isu tentang gerakan sosial baru atau new social movement akhir-akhir ini gencar mewarnai wacana dan perdebatan dalam kehidupan sosial masyarakat. Tujuandari gerakan sosial baru (New Social Movement) adalah untuk menata kembali relasi negara, masyarakat dan perekonomian untuk menciptakan ruang publik yang di dalamnya terdapat wacana demokratis otonomi dan kebebasan individual.

Isu gerakan sosial lingkungan berawal dari banyaknya sampah plastik yang dihasilkan setiap manusia setiap tahu. Terlepas dari hal tersebut, beberapa individu lain sadar akan tindakannya yang merusak lingkungan dan berupaya untuk mengurangi perilakunya yang merusak lingkungan dan ekosistem. Salah satu gerakan sosial yang aktif mengencarkan pengurangan penggunaan sampah plastik adalah gerakan sosial stop penggunaan sedotan plastik atau yang lebih di kenal sebagai gerakan \#NoStrawMovement. Gerakan ini mengajak masyarakat untuk peduli dengan dampak sedotan plastik sekali pakai terhadap lingkungan. \#NoStrawMovement juga mengajak para pelaku industri untuk peduli dengan dampak lingkungan dari sedotan plastik dengan tidak lagi menyediakan sedotan plastik. Sebagai permulaan, gerakan ini berhasil menggandeng satu perusahaan waralaba makanan cepat saji terbesar di Indonesia untuk berkomitmen tidak menyediakan lagi sedotan plastik di jaringan gerai mereka dan saat ini sudah ada 4 perusahaan multinasional lain yang ikut bergabung disamping pemilik usaha kecil dan menengah lokal yang mereka edukasi di sejumlah tempat. Gerakan tanpa sedotan plastik atau \#Nostrawmovement yang sukses dijalankan di Indonesia, kemudian diadopsi oleh negara tetangga, Singapura. Gerakan ini kini juga sedang dikaji untuk ditiru oleh Filipina dan Australia.

\section{DAFTAR PUSTAKA}

Ahmad, M. (2010). Pendidikan Lingkungan Hidup Dan Masa Depan Ekologi Manusia. Forum tarbiyah vol. 8, No. 1, Juni 2010, 8, 57-71.

Ananda, P. (June 5, 2018). Bahaya Sampah Plastik Jangka Panjang yang Tidak Anda Duga. Oke Zone Tv. Retrieved from: https://lifestyle.okezone.com/read/2018/06/05/481/1906793/bahaya-sampahplastik-jangka-panjang-yang-tidak-anda-duvga

Anto, G. (November 26, 2018). \#\#NoStrawMovement : Larangan Penggunaan Sedotan Plastik. Namalo News. Retrieved from: https://www.namalonews.com/2018/11/26/no-straw-movement-laranganpenggunaan-sedotan-plastik/

Farma Rahayu, M. I., F. Susanto, A., \& Sukma Muliya, L. (2018). gerakan sosial pemberdayaan hukum dalam pelestarian fungsi lingkungan hidup berbasis kearifan lokal melalui metode patanjala. bina bukum lingkungan, 2(1), 47-56.

https://doi.org/10.24970/jbhl.v2n1.5 
Intan, G. (November 19, 2018). Selamatkan Lingkungan, Gerakan Tanpa Sedotan Plastik Mulai Nge-Trend di Masyarakat. VOA Indonesia. Retrieved From: https://www.voaindonesia.com/a/selamatkan-lingkungan-gerakan-tanpa-sedotanmulai-nge-trend-di-masyarakat/4664637.html

Juniman, P, T. (July 02, 2018). Gerakan Tanpa Sedotan, Cara Baru Kurangi Sampah Sedotan Plastik. CNN News Indonesia. Retrieved From: https://www.cnnindonesia.com/gayahidup/20180629142643-282-310154/gerakan-tanpa-sedotan-cara-baru-kurangisampah-plastik

Madubrangti, D. (2015). B. Herry Priyono, Anthony Giddens: suatu pengantar. Cetakan kedua. Jakarta: Kepustakaan Populer Gramedia, 2003, 98 hlm. (Cetakan pertama 2002). ISBN 979-9023-85-8. Harga: Rp15.000,00 (soft cover). Wacana, Journal of the Humanities of Indonesia, 10(1), 168. https://doi.org/10.17510/wjhi.v10i1.185

Ritzer, G. \& Douglas, G. J. (2011). Teori Sosiologi Klasik Suatu Pengantar. Bantul: Kreasi Wacana.

Sari, D. K., \& Siahainenia, R. R. (2017). Gerakan Sosial Baru di Ruang Publik Virtual pada Kasus Satinah. Jurnal Ilmu Komunikasi, 12(1). https:// doi.org/10.24002/jik.v12i1.446

Suharko, -. (2006). Gerakan Sosial Baru di Indonesia: Repertoar Gerakan Petani. Jurnal Ilmu Sosial Dan Ilmu Politik, 10(1), 1-34. https:/ / doi.org/10.22146/JSP.11020

Sukmana, O. (2013). Konvergensi Antara Resource Oriented Theory Dalam Studi Gerakan. Ilmu Kesejabteraan Sosial, (1).

Ushuluddin, D. F. (n.d.). Dosen Fakultas Ushuluddin, LAIN Raden Intan Lampung, Prodi Pemikiran Politik Islam. * .

Yuanjaya, P. (2018a). Modal Sosial Dalam Gerakan Lingkungan: Studi Kasus Di Kampung Gambiran Dan Gondolayu Lor, Kota Yogyakarta. Natapraja, 3(1), 57-72. https://doi.org/10.21831/jnp.v3i1.11958

Yuanjaya, P. (2018b). Modal Sosial Dalam Gerakan Lingkungan: Studi Kasus Di Kampung Gambiran Dan Gondolayu Lor, Kota Yogyakarta. Natapraja, 3(1). https://doi.org/10.21831/jnp.v3i1.11958. 